\title{
A transmission electron microscope study of white mica crystallite size distribution in a mudstone to slate transitional sequence, North Wales, UK
}

\author{
R.J. Merriman ${ }^{1}$, B. Roberts ${ }^{2}$, and D.R. Peacor ${ }^{3}$ \\ ${ }^{1}$ British Geological Survey, Keyworth, Nottingham, NG12 5GG, UK \\ ${ }^{2}$ Department of Geology, Birkbeck College, Malet Street, London WC1 1EX, UK \\ ${ }^{3}$ Department of Geological Sciences, University of Michigan, Ann Arbor, Michigan 48109, USA
}

Received February 1, 1990 / Accepted June 14, 1990

\begin{abstract}
High-resolution transmission electron microscopy (HRTEM) measurements of the thickness of white mica crystallites were made on three pelite samples that represented a prograde transition from diagenetic mudstone though anchizonal slate to epizonal slate. Crystallite thickness, measured normal to (001), increases as grade increases, whereas the XRD measured $10 \AA$ peakprofile, the Kubler index, decreases. The mode of the TEM-measured size population can be correlated with the effective crystallite size $\mathrm{N}_{(001)}$ determined by XRD. The results indicate that the Kubler index of white mica crystallinity measures changes in the crystallite size population that result from prograde increases in the size of coherent X-ray scattering domains. These changes conform to the Scherrer relationship between XRD peak broadening and small crystallite size. Lattice 'strain' broadening is relatively unimportant, and is confined to white mica populations in the diagenetic mudstone. Rapid increases in crystallite size occur in the anchizone, coincident with cleavage development. Changes in the distribution of crystallite thickness with advancing grade and cleavage development are characteristic of graingrowth by Ostwald ripening. The Kubler index rapidly loses sensitivity as an indicator of metapelitic grade within the epizone.
\end{abstract}

\section{Introduction}

Measurements of illite crystallinity or Kubler index (Kubler 1964, 1967, 1968) have been widely applied to the study of low and very low grade metamorphism of pelitic rocks: for reviews see Frey (1987), Kisch (1983, 1989a). The Kubler index is the width at half-height of the mica $10 \AA(001 / 002)$ X-ray diffraction (XRD) peak made on oriented $<2 \mu \mathrm{m}$ fractions. Because of its relative simplicity, the technique has been applied to regional surveys of metapelitic grade (eg Árkai 1977; Âr-

Offprint requests to: R.J. Merriman kai et al. 1981; Kisch 1980; Roberts and Merriman 1985; Robinson and Bevins 1986; Pesquera and Velasco 1988; Fortey 1989; Roberts et al. 1990). Where the technique has been used for regional studies, it is clear that a variety of micas contribute to the XRD measurement, including illite, ammonium-illite, "sericite", phengite, muscovite and paragonite; hence the term "white mica crystallinity' (Merriman and Roberts 1985) is more appropriate than 'illite crystallinity' for regional surveys of grade.

Despite the usefulness of the technique in characterising low-grade metapelitic terrains, the underlying causes of measured variation in $10 \AA$ peak-width are poorly understood. The term crystallinity is not defined and implies, variously, differing degrees of ordering or lattice strain or heterogeneity in structure and/or chemistry between or within 2:1 sheets, or variation in crystallite size. Several geological and mineralogical variables also affect $10 \AA$ peak-width and have been enumerated by Frey (1987); standardization of measuring and machine conditions has been dealt with by Kisch $(1983,1989$ b); and the effects of sample preparation techniques by Kisch and Frey (1987).

Crystallographically, two factors, crystallite size and lattice strain or disorder, largely determine the profile of a diffraction peak from a polycrystalline, homogeneous phase (Klug and Alexander 1974). Peak broadening $(\beta)$ caused by small crystallite size is approximated by the Scherrer equation:

$\beta=\frac{K \lambda}{N d \cos \theta}$

where $K$ is a constant (0.9), $\lambda$ is the radiation wavelength (1.5418 $\AA$ for $\left.\mathrm{CuK} \alpha_{1}\right), d$ is the interplanar spacing for a given diffraction peak ( $9.98 \AA$ for the Kubler index), $\theta$ is the Bragg diffraction angle (in radians) and $N$ is the effective size of a population of crystallites (ie the coherent X-ray scattering domains). In terms of the Kubler index, $N_{(001)}$ is the effective number of $10 \AA$ units. Several authors have invoked the Scherrer relation- 
ship to explain measured variation in the $10 \AA$ peakprofile (Weber et al. 1976; Árkai and Tóth 1983; Kubler 1984; Merriman and Roberts 1985), but only Kreutzberger and Peacor (1988) have recorded crystallite thickness using direct TEM observations.

Lattice strain is a term widely used in crystallographic and metallurgical literature to describe non-periodic features of crystal structure. Such features are commonly defined by their dimensionality as point-defects (vacancies), linear defects (dislocations) and planar defects (stacking faults, Wadsley defects, twin planes) (Veblen 1985). Although the term strain implies a response to stress acting on an originally strain-free lattice, many defects arise during crystal growth, polymorphic transformations and replacive chemical reactions. Non-periodic structures of the type commonly found in random mixed-layer phyllosilicates show one dimensional disorder parallel to $\mathrm{c}^{*}$. Such disorder does not necessarily impose a strain (sensu stricto) on the lattice but does affect the profile of the (001) diffraction peaks.

Probably the most important lattice disorder affecting the illite (001) $10 \AA$ peak-profile is expandability or swelling parallel to $c^{*}$ (Eberl and Velde 1989). Expandability results from hydrated smectite interlayers within illite crystallites and, according to Środoń et al. (1990), also from hydrated basal surfaces at tops and bottoms of crystallites. In a detailed study of sericite from the Silverton caldera (Colorado), Eberl et al. (1987) found that the Kubler index can be correlated with expandability and is a function of crystallite size. In a subsequent study of the same samples Eberl and Środoń (1988) used the Warren-Averbach method to measure particle thickness and distribution and concluded that progressive hydrothermal recrystallisation by Ostwald ripening had affected the sericite. Środon et al. (1990) used high-resolution transmission electron microscopy (HRTEM) and XRD to measure expandability in a bentonite and obtained good correlation between the techniques, particularly when the top and base of mixed-layer crystallites were not counted as smectite. An illite-crystallite size and lattice-disorder measurement proposed by Eberl and Velde (1989), combines XRD measurements of Kubler index and expandability, and is particularly useful for diagenetic grade mudstones.

In a TEM study of a continuous transitional sequence from mudstone to slate, Lee et al. $(1984,1986)$ noted that illite crystallite thickness increases as slaty cleavage develops. The study described here uses HRTEM lattice-fringe images to quantify changes in the population of sub-micron white mica crystallites of three metapelites in response to prograde regional metamorphism and cleavage development.

\section{Geology and sample descriptions}

The three samples studied represent a range in metamorphic grade from uncleaved, diagenetic ( $\sim$ zeolite facies) mudstones, through anchizonal slates (prehnite-pumpellyite/prehnite-actinolite facies), with a spaced cleavage, to epizonal (lower greenschist facies), penetratively cleaved slates. All three were essentially of the same origi-
Table 1. Chemical composition of three mudrocks from the Llanvirn series (Ordovician), North Wales

\begin{tabular}{|c|c|c|c|}
\hline & BRM 202 & BRM 169 & BRM 167 \\
\hline $\mathrm{SiO}_{2} \%$ & 52.08 & 49.87 & 56.10 \\
\hline $\mathrm{TiO}_{2}$ & 1.07 & 1.04 & 0.99 \\
\hline $\mathrm{Al}_{2} \mathrm{O}_{3}$ & 24.90 & 25.48 & 22.27 \\
\hline $\mathrm{Fe}_{2} \mathrm{O}_{3}$ & 9.36 & 10.32 & 8.89 \\
\hline $\mathrm{MgO}$ & 2.01 & 2.08 & 1.87 \\
\hline $\mathrm{CaO}$ & 0.34 & 0.34 & 0.08 \\
\hline $\mathrm{Na}_{2} \mathrm{O}$ & 0.75 & 1.02 & 0.59 \\
\hline $\mathrm{K}_{2} \mathrm{O}$ & 3.22 & 3.33 & 4.34 \\
\hline $\mathrm{MnO}$ & 0.14 & 0.98 & 0.20 \\
\hline $\mathrm{P}_{2} \mathrm{O}_{5}$ & 0.13 & 0.24 & 0.07 \\
\hline LOI & 6.51 & 5.01 & 4.13 \\
\hline Total & 100.52 & 99.71 & 99.53 \\
\hline Ba ppm & 684 & 704 & 1051 \\
\hline $\mathrm{Ce}$ & $132.9^{\mathrm{a}}$ & 98 & 93 \\
\hline $\mathrm{Co}$ & $40.3^{a}$ & 27 & 11 \\
\hline $\mathrm{Hf}$ & $3.71^{\mathrm{a}}$ & 4 & 3 \\
\hline $\mathrm{La}$ & $61.7^{\mathrm{a}}$ & 31 & 35 \\
\hline $\mathrm{Nb}$ & 21 & 22 & 21 \\
\hline $\mathrm{Ni}$ & 68 & 73 & 51 \\
\hline $\mathrm{Rb}$ & 148 & 161 & 187 \\
\hline $\mathrm{Sm}$ & 9.89 & 4 & 8 \\
\hline $\mathrm{Sr}$ & 118 & 152 & 91 \\
\hline $\mathrm{Ta}$ & $1.62^{\mathrm{a}}$ & 3 & $<2$ \\
\hline Th & $21.6^{a}$ & 12 & 9 \\
\hline $\mathrm{Y}$ & 35 & 28 & 28 \\
\hline $\mathrm{Yb}$ & $2.68^{\mathrm{a}}$ & 4 & 4 \\
\hline $\mathrm{Zr}$ & 133 & 119 & 137 \\
\hline
\end{tabular}

a Instrumental neutron activation analysis; all other data by X-ray fluorescence analysis.

BRM 202 = Diagenetic mudstone, D. bifidus biozone; Afon Seiont, Caernarfon. National Grid Reference SH 489 613; BRM $169=$ Anchizone grade slate; Cwm Pennant. National Grid Reference SH 534 485; BRM $167=$ Epizone grade slate; Cwm Pennant. National Grid Reference SH 517445

nal silty mudrock lithology (Table 1), which is characteristic of the Llanvirn Series (Ordovician) in the northern sector of the Lower Palaeozoic Welsh marginal basin (Fig. 1). The geology of the area has been summarized by Roberts (1979), and Howells et al. (in press), and the regional metamorphism is detailed by Roberts (1981) and Roberts and Merriman (1985). A brief summary of the regional metamorphism is included here.

Lowest grade diagenetic pelites (Metapelite stage I, Fig. 1) are uncleaved or possess a spaced irregular fracture-cleavage with Kubler indices $>0.43 \Delta^{\circ} 2 \theta ;<2 \mu \mathrm{m}$ fractions are dominated by $\mathrm{K}$ - and Na-micas which lack diagnostic polytypic XRD reflections and were therefore assumed by Merriman and Roberts (1985), to be the $1 \mathrm{Md}$ polytype. Anchizonal grade (stage II) metapelites are characterised by Kubler indices in the range $0.26-0.43 \Delta^{\circ} 2 \theta$, and variable development of cleavage; the $2 \mathrm{M}_{1}$ mica polytype is common in well-cleaved anchizonal metapelites, and both $\mathrm{Na}$ - and K-mica occur, commonly interstratified. Highest grade epizonal metapelites (stage III) are strongly cleaved slates with Kubler indices $<0.26 \Delta^{\circ} 2 \theta$; the $2 \mathrm{M}_{1}$ mica polytype occurs widely both as $\mathrm{K}$ mica (muscovite and phengite) and paragonite. The regional metamorphism occurred at a relatively high field gradient, possibly as high as $50^{\circ} \mathrm{C} \mathrm{Km}^{-1}$ (Bevins and Merriman 1988) and culminated during Acadian (early Devonian) deformation and cleavage development.

Sample BRM 202 is an uncleaved diagenetic mudstone collected from a sequence of interbedded mudstones and shales $2 \mathrm{Km}$ SE of Caernarfon Castle (Fig. 1; Table 1). The mudstone beds, 


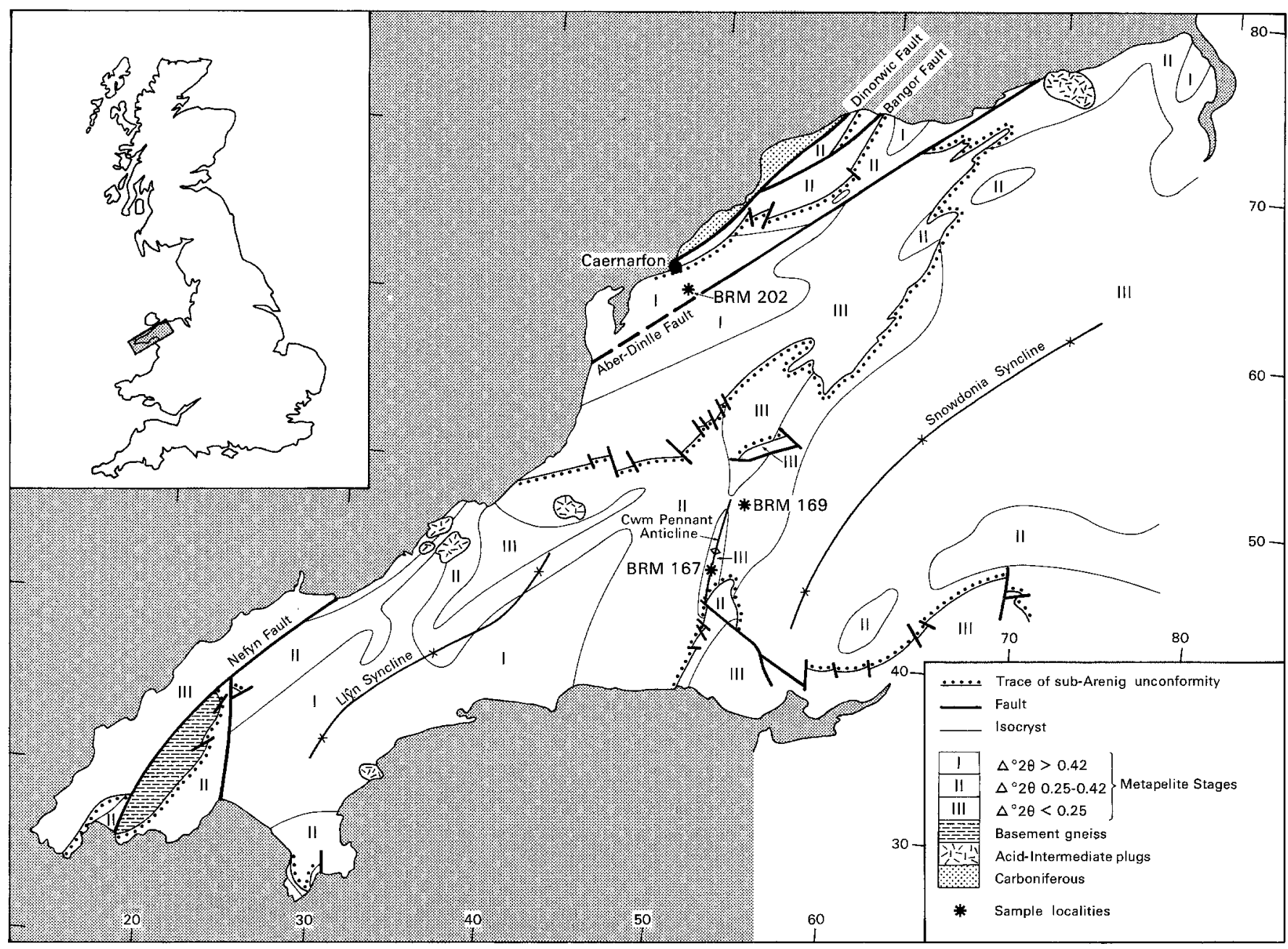

Fig. 1. Sketch map of North Wales (excluding Anglesey) showing pattern of low-grade regional metamorphism and location of samples. National grid lines are at $10 \mathrm{~km}$ intervals

from the $D$. bifidus biozone of the Llanvirn Series, are up to $1 \mathrm{~m}$ thick, occasionally show internal silty lamination or bioturbation structures, and retain blocky or polygonal shrinkage structures. A back-scattered electron image (BSEI) of a thin section shows a compactional bedding-parallel fabric, but no evidence of tectonically induced cleavage (Fig. $2 \mathrm{~A}$ ). Detrital muscovite flakes, many showing compactional buckling, chloritic granules and grains of quartz and alkali-feldspar are dispersed through a matrix of finegrained phyllosilicates. An XRD analysis of the $<2 \mu \mathrm{m}$ fraction shows major illite and chlorite, subordinate mixed-layer illite/smectite $(\mathrm{I} / \mathrm{S})$ and mixed-layer $\mathrm{K}$-mica/Na-mica, and minor discrete smectite, pyrophyllite and quartz. Na-micas form approximately $30 \%$ of the white mica population (Merriman and Roberts 1985 , Table 1). A scanning transmission electron microscope (STEM) study of the mixed-layer illite/smectite (Jiang et al., in press), shows that both ordered I/S with rectorite-like compositions, and random I/S are present. In the same study, TEM lattice-fringe images show that much of the matrix consists of intergrown sub-parallel packets of illite (2-layer polytype) and chlorite. The absence of compactional deformation of the matrix and the closely intergrown texture of the illite and chlorite matrix suggests that diagenetic growth occurred after maximum compactional lithification of the mudstone had been achieved (Jiang et al., in press). Texturally, the matrix phyllosilicates of BRM 202 closely resemble the Gulf Coast sample from 5500 metres depth, described by Lee et al. (1985, Fig. 4).
Sample BRM 169 is an anchizonal blue-grey slate from the Llanvirn Series (Nantmor Group) cropping out on the eastern limb of the Cwm Pennant Anticline (Fig. 1; Table 1). A BSEI shows an anastomosing slaty cleavage defined by oriented neomorphic white mica and chlorite flakes in P-domains (Fig. 2B). These are separated by poorly-oriented phyllosilicates and mineral grains in Q-domains (Knipe 1981), including chlorite-mica stacks, of detrital origin (Milodowski and Zalasiewicz, in press), detrital mica, quartz and rare feldspar. Chloritoid occurs as syn- and post-tectonic micro-porphyroblasts (Roberts et al. 1989). Electron microprobe analyses of chlorites in P-domains and in Q-domains (chlorite-mica stacks) are closely similar (Roberts et al. 1989), indicating that the mafic phyllosilicates in the two textural domains were in equilibrium. An XRD analysis of the $<2 \mu \mathrm{m}$ fraction shows predominantly $2 \mathrm{M}_{1} \mathrm{~K}$-mica with chlorite, regular mixed-layer paragonite/phengite (Frey 1969), discrete paragonite and minor quartz. It should be noted that Livi et al. (1988) have suggested that the $\mathrm{K} / \mathrm{Na}$-mica possesses irregular $\mathrm{K}$-rich and $\mathrm{Na}$-rich domains rather than true mixed-layer ordering. Na-mica forms about $40 \%$ of the white mica population (Merriman and Roberts 1985, Table 2).

Sample BRM 167 is a blue-grey slate of epizonal grade from th Llanvirn Series (Nantmor Group), cropping out in the core of the Cwm Pennant Anticline (Fig. 1; Table 1). The BSEI shows a well-developed anastomosing slaty cleavage defined by strongly orientated neomorphic white mica and chlorite flakes and rutile needles in P-domains (Fig. 2C). Randomly oriented phyllosilicates, 


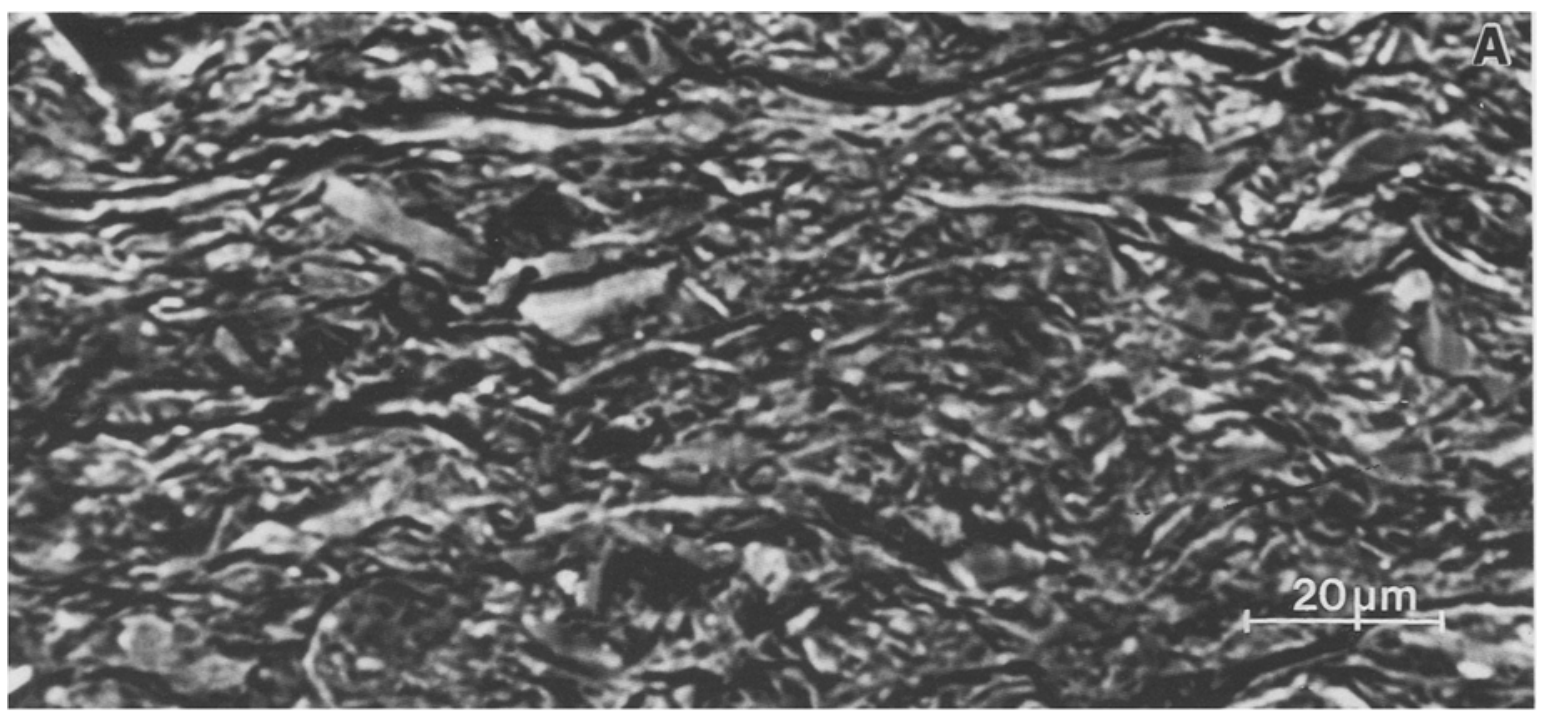

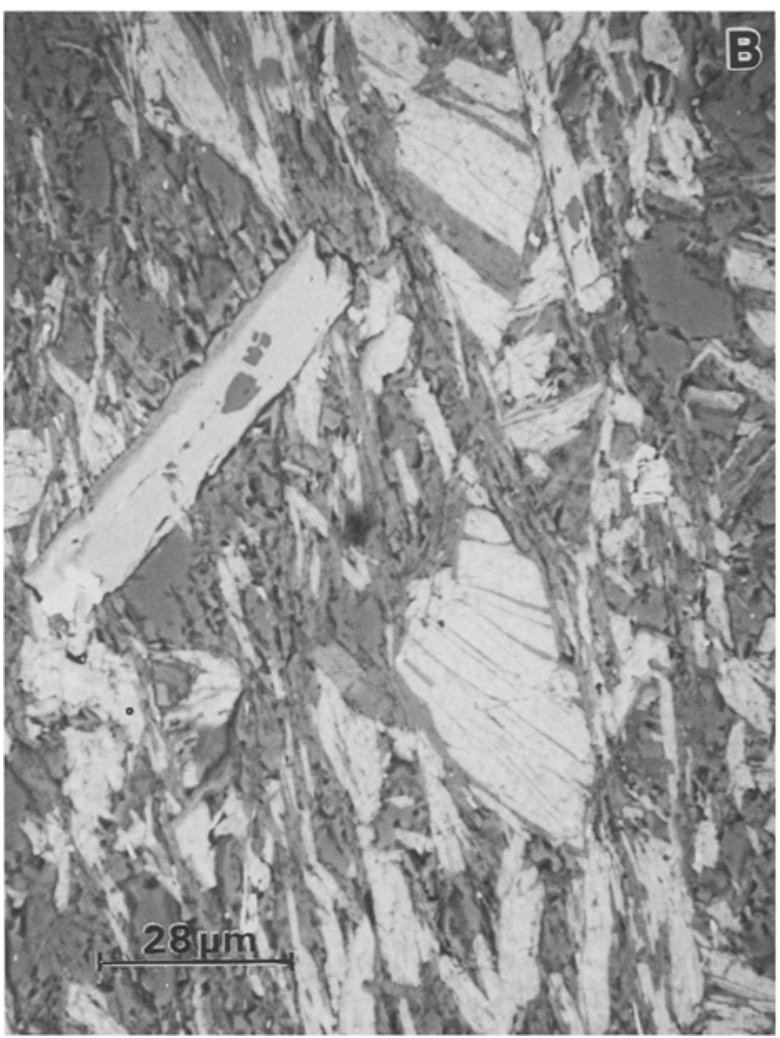

Fig. 2A-C. Back-scattered electron images (BSEI) of samples studied: A Late diagenetic grade mudstone sample BRM 202, beddingparallel fabric is orientated E-W; B anchizonal slate sample BRM 169 , oriented neomorphic phyllosilicates in spaced cleavage (P-

including chlorite-mica stacks, detrital white mica and quartz grains occupy Q-domains, which are fewer and narrower than those in sample BRM 169. Detrital chlorite-mica stacks show clear evidence of rotation and extension in the cleavage. An XRD analysis of the $<2 \mu \mathrm{m}$ fraction shows major $2 \mathrm{M}_{1}$ phengitic mica and chlorite, subordinate discrete paragonite and minor quartz and rutile. Less than $20 \%$ of the white micas are paragonitic.

Major and trace-element analyses emphasize the similarities of the samples (Table 1). Variations in major elements Si and Al largely reflect the varying proportions of silt and clay which are typical of mudrocks. Ratios of $\mathrm{Mg} / \mathrm{Fe}^{2+}$ show little variation between

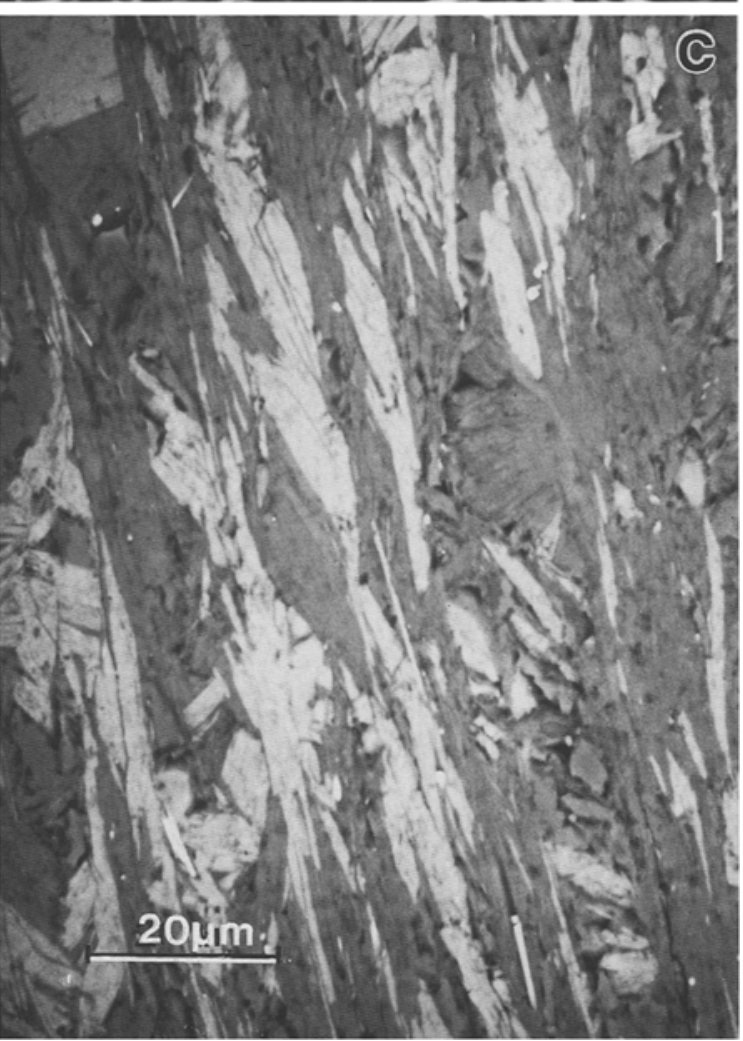

domains of Knipe 1981) are approximately N-S; C epizonal slate sample BRM 167, phyllosilicates in P-domains are approximately $\mathrm{N}-\mathrm{S}$

samples, suggesting that mafic detrital components in all three had a similar provenance. Fine-grained mafic mineral- and rock-fragments of volcanogenic origin were probably altered initially to saponite. Larger fragments are now represented by chlorite-mica stacks in samples BRM 167 and 169, and the chloritic granules in BRM 202 (Milodowski and Zalasiewicz, in press). A marked decrease in $\mathrm{CaO}$ with increase in grade probably reflects the progressive elimination of smectite interlayers in high-grade slates, a change also indicated by the progressive decrease in loss-on-ignition (LOI) values. Some $\mathrm{CaO}$ however is retained in apatite grains in BRM 169. Relatively high $\mathrm{MnO}$ in the latter sample is reflected 
in the occurrence of chloritoid (Roberts et al. 1989). Trace-element variations caused by mobility during prograde phyllosilicate transitions are shown by some large-ion lithophile (LIL) elements: $\mathrm{Ba}$ and $\mathrm{Rb}$ follow $\mathrm{K}_{2} \mathrm{O}$ which increases with grade; $\mathrm{Sr}$ follows $\mathrm{CaO}$ which generally decreases with grade. Immobile trace-elements particularly $\mathrm{Nb}, \mathrm{Ta}, \mathrm{Y}$ and $\mathrm{Zr}$, show minor variation only, further emphasising similaries in original lithology and provenance.

\section{Transmission electron microscopy}

Samples were prepared as sticky-wax mounted thin sections oriented approximately normal to the dominant planar fabric, lamination or cleavage, following the methods detailed by Ahn and Peacor (1986). Carbon-coated thin sections were then examined by optical microscopy and scanning electron microscopy (Fig. 2), to select suitable areas for TEM study. An aluminium washer was glued to the areas selected which were detached from the thin section and ion-milled. Lattice-fringe images were obtained with a JEOL JEM-100 CX scanning transmission electron microscope operated at $120 \mathrm{kV}$ with a beam current of $\sim 20 \mu \mathrm{A}$. Most images were obtained at $66 \times 10^{3}$ or $100 \times 10^{3}$ magnification.

\section{Lattice-fringe images}

TEM images of the diagenetic mudstone sample BRM 202 are shown in Fig. 3. A typical textural relationship between matrix phyllosilicates and detrital grains is illustrated by Fig. $3 \mathrm{~A}$. Closely intergrown sub-parallel packets of chlorite and illite show only minimal evidence of compactional deformation of the matrix, despite a range of $\sim 90^{\circ}$ in the contact angle of the subspherical surface of the quartz grain with the planar fabric of the chlorite- and mica-packets. Similar textures were seen wherever clast/matrix contacts were imaged. They contrast strongly with textures recorded from Gulf Coast shale samples at $1750 \mathrm{~m}$ depth, where early diagenetic smectite wraps around detrital grains as a result of compactional distortion of the matrix clay (Lee et al. 1985). The minimal evidence of matrix compaction in BRM 202 indicates that the illite and chlorite intergrowths developed after maximum compaction had been attained and are probably late diagenetic. The intergrowths typically show slight curvature of illite- and chlorite-packets which is in part an effect of grain boundaries transforming from low angles, with associated layer terminations, to parallelism and layer continuity (Fig. 3B). Curvature of illite- and chlorite-packets, clearly imaged in Fig. $3 \mathrm{C}$, results in changing contrast due to variable-layer orientation. Poorly resolved 'voids' may also result from misorientation of layers or from beam damage that has caused layer separation. Some poorly resolved lattice fringes represent collapsed smectite interlayers (Jiang et al. in press). Given the general absence of compactional deformation noted above, the curvature and high density of low-angle boundaries and associated layer terminations appear to be inherited from an early diagenetic smectite-rich matrix of volcanogenic origin (Roberts and Merriman 1990). The high proportion of chlorite in the matrix of BRM 202, as compared with typical Gulf Coast shale (Ahn and Peacor 1986), suggests a high saponitic component in the precursor smectite.
Typical TEM images of the anchizonal slate sample BRM 169 are shown in Fig. 4. Mottled white mica packets are significantly thicker than those imaged in BRM 202 , and generally show a lower density of layer terminations and fewer curved crystals (Fig. 4A). However, the larger mica packets commonly enclose stacks of smaller mica packets (both 2-layer polytypes), where the density of low-angle grain boundaries and associated layer terminations resemble textures found in the mudstone sample BRM 202. Figure 4B shows an enclosing mottled mica-packet overgrowing the basal packet of a stack of thin micas which coalesce normal to $\mathrm{c}^{*}$ and transform into the single thick packet. These appear to represent typical annealing textures of smaller crystals dissolved and simultaneously recrystallised into larger crystals which contain fewer imperfections. Grain boundaries between parallel mica-packets, marked by fringes of higher contrast and variable thickness, probably represent incoherent interfaces with a rotational component around $\mathrm{c}^{*}$. Layer separation, caused by $\mathrm{Na}$ migration under the electron beam (Fig. 4A, B), may occur along these grain boundaries. The presence of discrete paragonite-packets could not be identified from lattice-fringe images, but paragonite can be identified in some electron diffraction patterns (Fig. 4C). Diffuse 001 paragonite reflections with a periodicity of $\sim 9.6 \AA$ are progressively better resolved from $10 \AA$ phengite 001 's from 006 to 0012 reflections. Weak superlattice reflections with a periodicity of $\sim 20 \AA$ suggests that the phengite is a $2 \mathrm{M}$ polytype.

Lattice-fringe images of the epizonal slate sample BRM 167 are characterized by relatively large and defect-free white mica crystallites (Fig. 5), typically a 2layer polytype but, occasionally a $3 T$ polytype. Images show little evidence of the coalescing stacks of thin micapackets seen in BRM 169 (Fig. 4A, B), indicating that the relict diagenetic fabric has been more or less completely transformed by metamorphic recrystallisation. Crystallite thickness parallel to $\mathrm{c}^{*}$ is largely constrained by sub-parallel interleaved chlorite crystallites or very low-angle grain boundaries with other mica. A number of large $(>1000 \AA)$ thick mottled micas developed lenticular fissures after exposure to the electron beam (Fig. 5B). These are closely similar to beam-damaged paragonite textures described by Ahn et al. (1986) and Shau et al. (1990), and attributed to Na migration. Such textures thus confirm the XRD identification of paragonite in BRM 167, which is otherwise impossible to distinguish from muscovite or phengite on the basis of lattice-fringe periodicity. Fissure - wall damage may be several layers deep (Fig. 5C), but continuous fringes beyond are deflected undamaged. In detail, paragonitic micas appear to possess a greater density of dislocations (arrowed in Fig. 5C), than K-micas, and these may act as nuclei for fissure development under the electron beam.

\section{White mica crystallite size}

Size measurements were made on TEM lattice-fringe images using the photographic negatives on a microfiche 

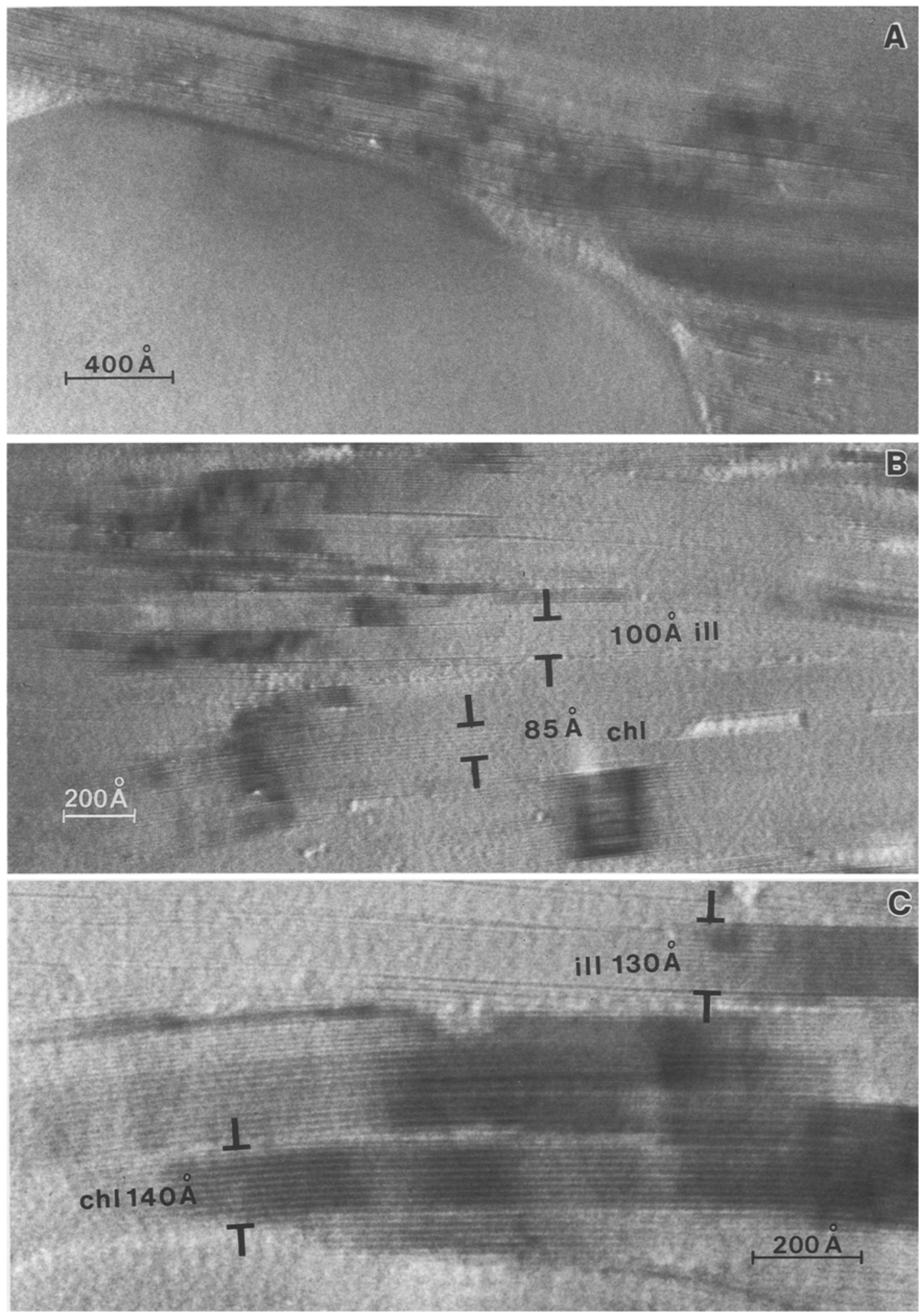

Fig. 3A-C. Transmission electron microscope images of mudstone sample BRM 202: A low-magnification image showing typical matrix textures adjacent to detrital quartz grains, note low degree

fringe image of thin chlorite and illite packets in mudstone matrix; $C$ lattice-fringe image of thin illite- and chlorite-packets showing low-angle boundaries and slight curvature 

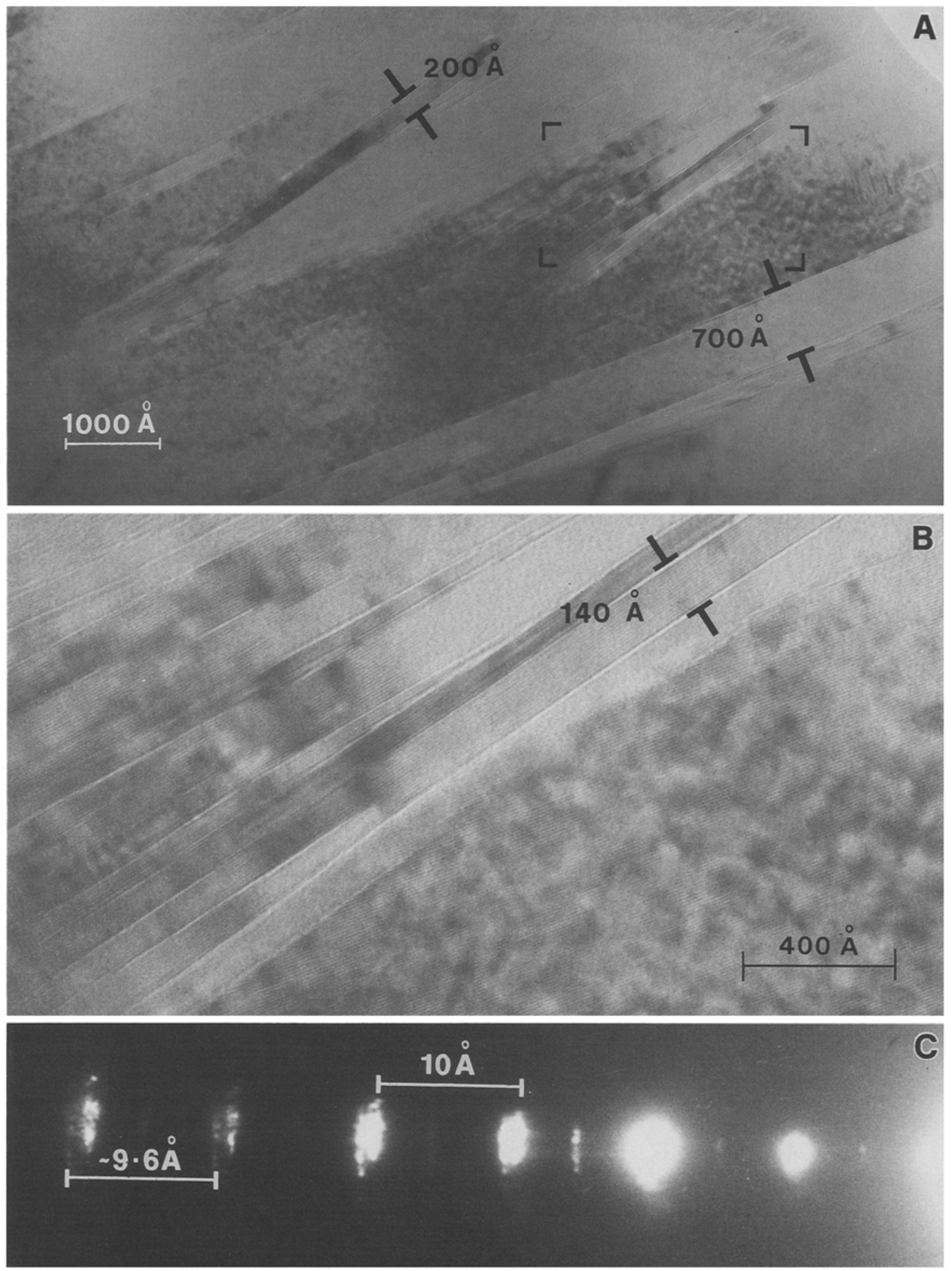

Fig. 4A-C. Transmission electron microscope images of anchizonal slate sample BRM 169: A sub-parallel mottled white mica packets with intergrown thin coalescing white mica packets; $\mathbf{B}$ detail of

A showing thick mottled mica-packet overgrowing basal packet of a stack of thin micas; C electron diffraction pattern of (001)-layer of intergrown phengite $(10 \AA)$ and paragonite $(9.6 \AA)$

reader. The latter allowed magnification of 25 or 40 times, giving final magnifications of up to $4.10^{6}$ times the original size. With these conditions the periodicities of the two principal phyllosilicates present, $10 \AA$ white mica and $14 \AA$ chlorite, are readily distinguished. Small

illite packets, such as those occuring in the mudstone BRM 202, were measured by counting the number of regularly spaced $10 \AA$ fringes parallel to $\mathrm{c}^{*}$, between obvious discontinuities in the sequence of layers. Discontinuities include: grain boundaries between micas and 

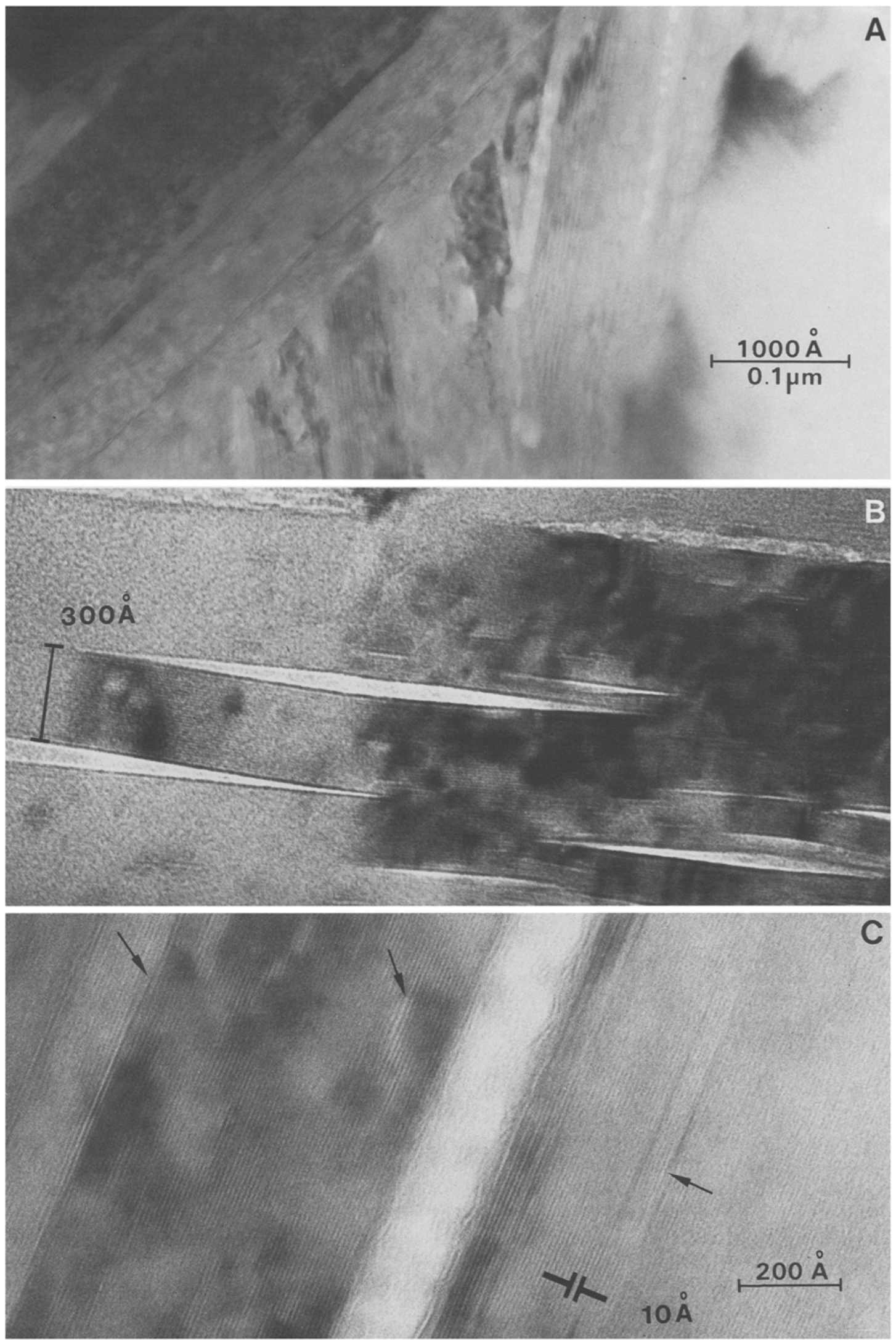

Fig. 5A-C. Transmission electron microscope images of epizonal slate sample BRM 167: A low-magnification image showing large mottled white mica packets; thin chlorite packet is interleaved in mica, running bottom left to top right; $\mathbf{B}$ lenticular fissures in para- gonite, characteristic of beam-damage-induced Na migration; $\mathbf{C}$ detail of layer disruption on fissure walls, note presence of several layer terminations (arrowed) close to fissure 


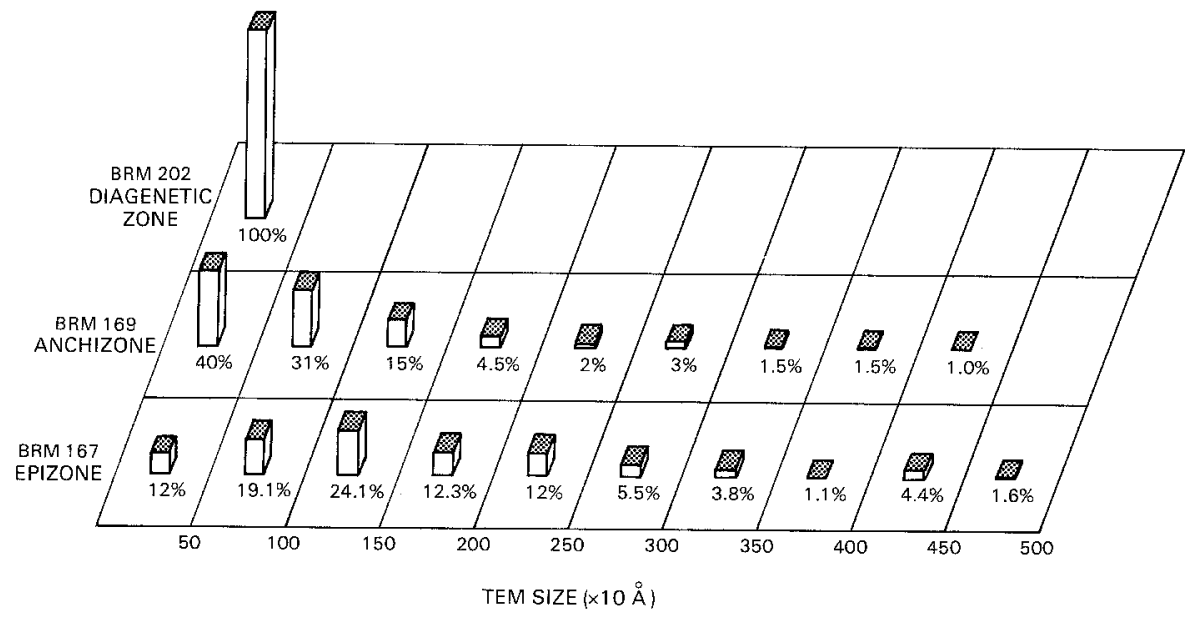

Fig. 6. Percentage block diagram showing distribution of white mica crystallite thickness as measured by TEM other phyllosilicates, mainly chlorite; low-angle grain boundaries between sub-parallel mica-packets; highcontrast fringes with 10-12 A spacing separating parallel mica-packets and probably representing collapsed smectite interlayers; and tapering fringes in parallel micapackets representing stacking faults or layer terminations (dislocations). Regular and random mixed-layer illite/smectite crystallites in BRM 202 (Jiang et al., in press), were not measured, nor were single layers of $\sim 10 \AA$ spacing, possibly collapsed smectite interlayers, within chlorite packets. Hence, illite packets showing a discontinuity which is eliminated normal to $\mathrm{c}^{*}$, such as a layer termination (edge dislocation) or coalescing smaller packets, may be measured more than once. The rationale for this is that, in terms of the Scherrer size, each defect-free distance parallel to c* acts as a crystallite, or more correctly a coherent scattering domain, in response to an incident $X$-ray beam, in contributing to the 'averaging' effect of diffraction.

Micas in samples BRM 169 and BRM 167 that showed abundant fissures caused by beam damage were not measured as single crystallites. Although it is likely that some fissures have exploited dislocations (i.e. possible scattering-domain boundaries), clearly much of the fabric is an artefact. Apart from avoiding beam-damaged micas, discrimination between $\mathrm{Na}$ - and $\mathrm{K}$-mica was impossible. Measurements from samples BRM 167 and BRM 169 therefore include predominantly those from $\mathrm{K}$-mica, plus those from subordinate $\mathrm{Na}$-micas both as discrete paragonite and as mixed-layer paragonite/phengite.

Larger, defect-free mica crystallites of 50 or more fringes were usually measured with a ruler, having first calibrated the $10 \AA$ periodicity for the microfiche screen magnification used. Inaccuracies introduced by this measuring technique are less than $\pm 5 \%$. Micas thicker than the TEM field at $66 \times 10^{3}$, effectively those with crystallite thicknesses larger than $1 \mu \mathrm{m}$, were not imaged. In practise only 7 mica crystallites of a total of 1039 measurements $(0.7 \%)$, exceeded $0.5 \mu \mathrm{m}$ in thickness.

The size data are summarised in a percentage-block diagram, Fig. 6 . It is clear that white mica crystallite thickness increases as grade increases. Crystallite thickness does not exceed $0.05 \mu \mathrm{m}(500 \AA)$ in the matrix of the diagenetic mudstone. In the anchizonal slate $40 \%$ of the crystallite population retain thicknesses equivalent to those in the mudstone; this falls to $12 \%$ in the epizonal slate. As grade increases so the proportions of larger mica crystallites increase, probably reflecting the growth of neomorphic white micas in oriented P-domains and their continued development at the expense of micas in Q-domains (Fig. 2B, C). The relative distribution of crystallite-size populations is similar to those of sericite samples described by Eberl and Środon (1988), and most likely results from progressive recrystallisation by Ostwald ripening.

Detailed plots of the mica-size populations are shown in Fig. 7. The population in the diagenetic mudstone sample BRM 202 has a mean thickness of 11.6 $(10 \AA)$ layers per crystallite, based on measurements of lattice-fringe images of 489 crystallites (Fig. 7A). The distribution is positively skewed towards larger sizes with a population mode in the 5-10 layer $(50-100 \AA)$ size interval; $95 \%$ of the population has a crystallite thickness of less than 25 layers. A mean Kubler index of $1.168( \pm 0.03)^{\circ} 2 \theta$ was determined from 10 XRD scans across the $10 \AA$ peak from the $<2 \mu \mathrm{m}$ fraction of $\mathrm{BRM}$ 202. This value was corrected to an effective crystallite thickness $\mathrm{N}_{(001)}$ of $\sim 7(10 \AA)$ layers using the Scherrer relationship (Table 2; Fig. 8). The effective crystallite size derived from XRD measurements corresponds with the largest portion ( $38 \%$ ) of the size population, at 5-10 layers, the portion which would be expected to most influence the XRD peak-profile.

In order to quantify the small amount of interlayered smectite that occurs in BRM 202 (Jiang et al., in press), expandability measurements were made from the Srodon intensity ratio, Ir (Środon 1984) which uses illite XRD peak intensities:

$I r=\frac{[(001) /(003)]_{\text {air dricd }}}{[(001) /(003)]_{\text {glycoiated }}}$

For BRM 202, $I r=1.8$, indicates approximately $7 \%$ expandability. This value corresponds to an effective crys- 

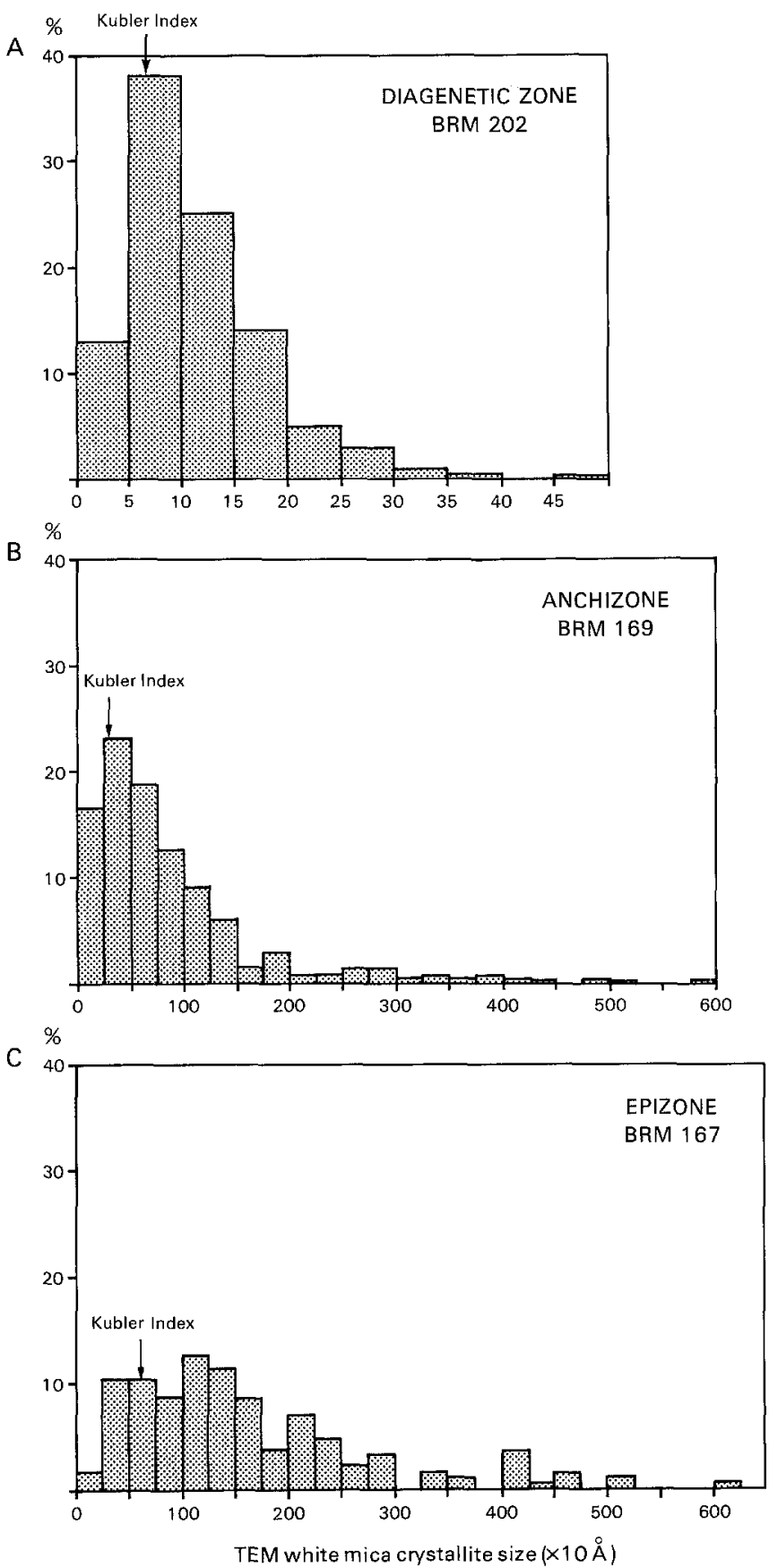

Fig. 7A-C. Histogram of thickness distribution of white mica crystallites as measured by TEM: A diagenetic-grade mudstone sample BRM 202; B anchizonal slate sample BRM 169; C epizonal slate sample BRM 167
Table 3. TEM and XRD measurements of white-mica crystallite thickness

\begin{tabular}{|c|c|c|c|c|}
\hline \multirow[t]{2}{*}{ Sample } & \multicolumn{3}{|c|}{$\begin{array}{l}\text { TEM measurements of white- } \\
\text { mica crystallite thickness }\end{array}$} & \multirow{2}{*}{$\begin{array}{l}\text { XRD measurements } \\
\text { of effective } \\
\text { crystallite } \\
\text { thickness } N_{\text {[001] }} \\
(\times 10 \AA)\end{array}$} \\
\hline & $\begin{array}{l}\text { No of } \\
\text { crystallites } \\
\text { measured }\end{array}$ & $\begin{array}{l}\text { Mode } \\
(\times 10 \AA)\end{array}$ & $\begin{array}{l}\text { Mean } \\
(\times 10 \AA)\end{array}$ & \\
\hline BRM 202 & 489 & 8 & 11.6 & 7 \\
\hline BRM 169 & 367 & 37.5 & 95 & 29 \\
\hline BRM 167 & 183 & 125 & 189 & 63 \\
\hline
\end{tabular}

tallite size $\mathrm{N}_{(001)}$ of $12-13$ layers, according to Eberl and Velde (1989; Fig. 3), and shows reasonably good agreement with the mean, but not the mode, of the TEM-measured size population (Table 3).

The crystallite-size population of the anchizonal slate BRM 169 is shown in Fig. 7B. It has a mean thickness of $95(10 \AA)$ layers based on measurements of latticefringe images of 367 crystallites, with $95 \%$ of the population possessing crystallite thicknesses of less than 300 layers. A mean Kubler index of $0.341( \pm 0.009)^{\circ} 2 \theta$ was determined from 4 XRD scans over the $<2 \mu \mathrm{m}$ fraction of BRM 167. This value converts to an effective crystallite size $\mathrm{N}_{(001)}$ of $\sim 29$ layers using the Scherrer relationship (Table 2; Fig. 8), and shows close correspondence with the dominant portion of the size population measured by TEM (Fig. 7B). Smectite is not detectable in BRM 169 and hence $I r \sim 1$ and expandability is $<1 \%$.

The crystallite-size population of the epizonal slate sample BRM 167 is based on lattice-fringe measurements of 183 crystallites (Fig. 7C). It has a mean crystallite thickness of $189(10 \AA)$ layers and $95 \%$ of the crystallites are less than 450 layers thick. A mean Kubler index of $0.212( \pm 0.007)^{\circ} 2 \theta$ was determined from 4 XRD scans across the $10 \AA$ peak of the $<2 \mu \mathrm{m}$ fraction. This value corresponds to an effective crystallite size $\mathrm{N}_{(001)}$ of 63 layers (Table 2; Fig. 8). Here the effective crystallite size determined by XRD does not correspond with the dominant portion of the size population measured by TEM. However BRM 167 shows a greater spread of sizes than the two lower-grade samples, and a much greater proportion of the crystallite population have thicknesses which are too large to influence XRD peak broadening (Fig. 8).

Table 2. Corrections for converting Kubler indices (B) to peak broadening $(\beta)$, and effective white mica crystallite size $\left[\mathrm{N}_{(001)}\right]$

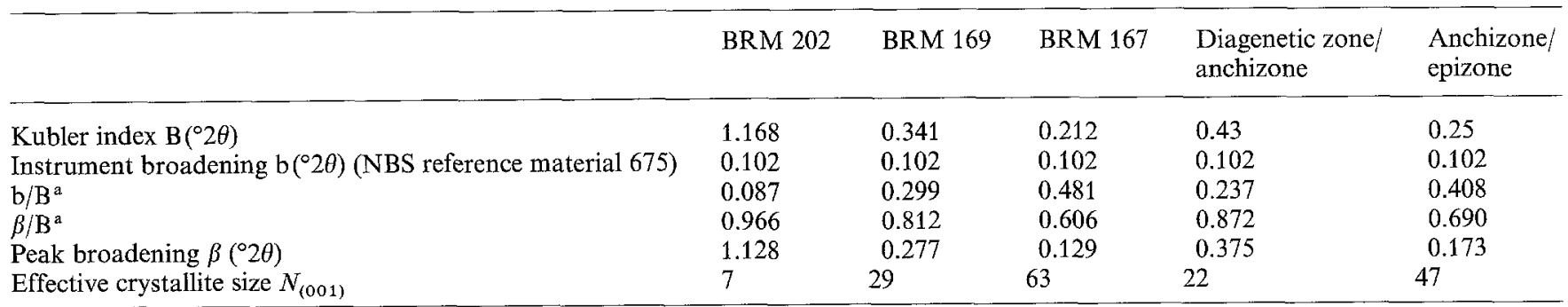

a Klug and Alexander (1974), Fig. 9-9 


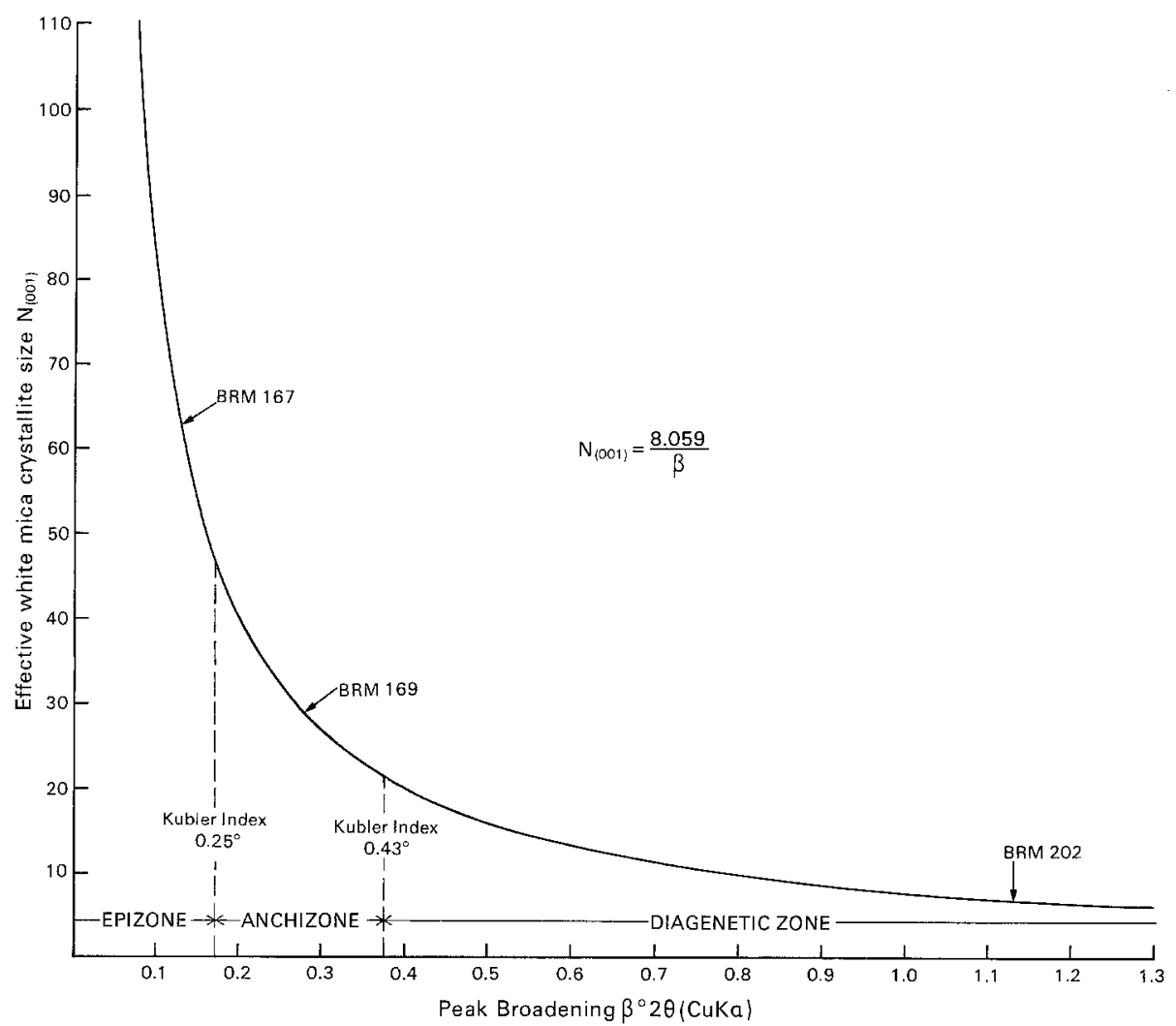

Fig. 8. Plot of peak broadening $\beta$ against effective white mica crystallite size $N_{(001)}$, from Scherrer equation. Peak-broadening values for samples BRM 202, 169, 167, and the boundaries of the diagenetic zone/ anchizone and anchizone/epizone, are shown in Table 2

\section{Discussion}

Attempts at correlation between the effective crystallite size of white micas determined by XRD and the crystallite thickness measured by TEM should take account of several factors:

1. It is assumed that the ion-thinned mudrock film within a washer of $3 \mathrm{~mm}$ diameter provides a representative area of that sample. The use of the SEM in selecting each area for TEM study greatly increased the likelihood that representative fields were selected - but the assumption remains.

2. The XRD measurements were made on the putative $<2 \mu \mathrm{m}$ fractions obtained by sedimentation after disaggregation of the samples, whereas TEM measurements were made on the untreated whole sample, but only recorded crystallites less than $1 \mu \mathrm{m}(10000 \AA)$ thick. This bias towards measurement of smaller crystals by TEM than by XRD is shown below to be unimportant since crystallite thicknesses greater than $\sim 1000 \AA$ do not influence $10 \AA$ peak broadening.

3 . The platy habit of micas leads to slower sedimentation rates than for grains of higher sphericity but of similar volume and mass. Standard modifications have been made to settling times to attempt to correct for this.

4. Both the anchizonal sample (BRM 169) and the epizonal sample (BRM 167) contain discrete paragonite and all three samples contain mixed-layer paragonite/ phengite. The amounts of discrete paragonite in BRM 169 and BRM 167 are small $(<20 \%)$ and therefore have little influence on the half-height widths of the $10 \AA$ peaks. In the TEM study Na- and K-micas could not be differentiated by lattice-fringe imagery and thus an error of unknown, but probably small, magnitude is introduced when discrete paragonite crystallites are measured and included in the white mica populations. The presence of mixed-layer paragonite/phengite, however, broadens the $10 \AA$ XRD peak but many such mixedlayer crystallites must have been measured as homogeneous $10 \AA$ crystallites by TEM. This is probably a very important factor since it operates to reduce the effective crystallite size measured by XRD but to increase the crystallite thickness measured by TEM. The extent of this factor can be assessed by comparing TEM and XRD measurements obtained from paragonite - free mudrocks: such a study, on mudrocks from the Southern Uplands of Scotland, is in progress.

5. In the case of a skewed distribution it is likely that the variate with the largest frequency, i.e. the mode of a population of crystallites, will exercise a greater influence on the XRD-measured effective crystallite thickness than the mean. In samples BRM 202 and BRM 169 , which show strongly skewed distributions, the modal crystallite thicknesses determined by TEM are similar to the effective crystallite size determined by XRD (Table 3); but in the case of BRM 167 the TEM-measured modal thickness is twice the XRD-measured effective crystallite size. The discrepancy may be a function of the fewer crystallites measured with increasing grain size and/or mixed-layered paragonite/phengite crystallites having been measured by TEM as single crystallites. But it is also likely that such discrepancies will result as the sensitivity limit of the Kubler index is approached. 
Despite such discrepancies it is evident that crystallite thickness of white micas increases with advancing metamorphic grade and the relationship between the TEM and XRD measurements indicates that the $10 \AA$ peak profile, the Kubler index, is largely controlled by crystallite thickness.

The relationship between peak broadening $(\beta)$ and effective crystallite size $\mathrm{N}_{(001)}$, expressed by the Scherrer equation, is shown graphically in Fig. 8. For the $10 \AA$ white mica peak-profile, the expression can be simplified to $\mathrm{N}_{(001)}=8.059 / \beta$, using the values given on $\mathrm{p} .27$. The observed peak width (B), used to determine the Kubler index, is the resultant of peak broadening $(\beta)$ due to small crystallite size, and instrument broadening (b). We determined the instrument-broadening parameter (b) by measuring the $10 \AA$ peak-width of a well-crystallized synthetic fluorophlogopite mica, NBS Reference Material 675, using as nearly as possible identical conditions to those used to measure the Kubler index (B). To this end, $1.5 \mathrm{gm}$ of Reference Material 675 was wet-sieved through $63 \mu \mathrm{m}$ mesh to remove small mica flakes which could cause peak broadening. As Reference Material 675 is supplied as ground 'powder' $<75 \mu \mathrm{m}$ mesh, the retained mica flakes represented the 63-75 $\mu \mathrm{m}$ size fraction. Optical examination showed that these flakes ranged $4-10 \mu \mathrm{m}$ in thickness. Five samples of this size fraction were prepared using an XRD-amorphous adhesive (Photomount) to stick the scattered flakes to glass slips with (001) parallel to the surface. Each of the five samples was scanned by XRD 15 times across the $10 \AA$ peak, using the same machine conditions as those used to determine the Kubler index (Merriman and Roberts 1985). A mean peak-width of $0.102( \pm 0.009)^{\circ} 2 \theta$ was obtained (Table 2). Kubler indices were corrected for instrument broadening to obtain the peak broadening due to small crystallite size by using the curve for low-angle reflections of Klug and Alexander (1974, Fig. 9-9). Corrected Kubler indices are shown in Table 2, and include those used in Fig. 1 to indicate the diagenetic zone/anchizone and anchizone/epizone boundaries.

The Scherrer curve shown in Fig. 8 consists of three distinct portions; one is sub-horizontal, the second has a rapidly increasing gradient and the third is sub-vertical. The sub-horizontal portion of the curve characterises the diagenetic zone in which the effective white mica crystallite size is small and consequently peak broadening and Kubler indices are large. Inaccuracies in establishing the maxima of broad peaks are compensated for by good measuring precision and small errors in $N_{(001)}$ values. Larger errors in the latter are likely where broadening occurs due to interlayered smectite. In such cases the combined Kubler index and intensity-ratio curves of Eberl and Velde (1989, Fig. 2) offer a superior method of estimating effective illite-crystallite size. The sub-vertical portion of the curve (Fig. 8), characterises the epizone where crystallite size rapidly increases in response to small changes in peak broadening.

In terms of the variation in the size of white mica crystallites the portion of the curve (Fig. 8) showing rapid change in gradient represents the anchizone and clearly marks the transition from diagenetic mudstones to epizonal slates. The low-grade limit of the anchizone is marked by a very low proportion of expandable material $(<1 \%$ expandability) and Ir values of $<1.1$. In North Wales it marks the first perceptible development of slate cleavage, at Kubler indices of $\sim 0.43 \Delta^{\circ} 2 \theta$. It also marks the point where effective crystallite size $\left(N_{(001)}=\sim 25\right)$ is sufficiently large for hkl reflections of the $2 \mathrm{M}_{1}$ mica polytype to be detectable on XRD traces of $<2 \mu \mathrm{m}$ fractions. Although a two-layer mica is abundantly present in the diagenetic mudstone BRM 202, $\mathrm{N}_{(\mathrm{hkl})}$ is too small and consequently the peak profile is too broad for XRD detection, given the low intensity of the $2 \mathrm{M}_{1}$ (hkl) reflections. A lack of diagnostic reflections led Merriman and Roberts (1985) to ascribe illitic micas in diagenetic mudstones from North Wales to the $1 \mathrm{Md}$ polytype. It is now clear that this assumption is incorrect, and that pre-XRD treatments of the type detailed by Austin et al. (1989) are necessary for the recognition of illite polytypes.

The upper limit of the anchizone used in Fig. 8, $N_{(001)}=47$, represents the Kubler index for the epizone/ anchizone transition in North Wales. Figure 8 clearly shows that the Kubler index is no longer a sensitive indicator of metapelitic grade as epizonal conditions advance.

Within the anchizone, white mica-crystallite size increases rapidly (Fig. 6), especially where cleavage development occurs in North Wales. Thus the size population, $\mathrm{N}<25$ layers, which is $95 \%$ characteristic of the diagenetic mudstone BRM 202, falls to less than $17 \%$ in the anchizonal slate BRM 169 , and below $2 \%$ in the epizonal slate BRM 167. The TEM evidence suggests that white mica growth takes place by dissolution and recrystallisation (Fig. 4A, B). In this fashion low-angle grain boundaries and layer dislocations inherited from diagenetic mudstones are annealed to form larger coherent crystallites. It is notable that even relatively high-angle grain boundaries show no evidence of deformation-induced strain or mechanical rotation during recrystallisation, an observation also recorded by Lee et al. (1986).

The increase in grain size which results from the annealing of a dispersed phase in a polycrystalline aggregate is described as Ostwald ripening (Ostwald 1900). Ostwald ripening proceeds by simultaneous growth and dissolution transferring material from small crystals to larger ones so as to reduce total-surface free-energy at the crystal-matrix interface. Crystal-size distribution measurements on hydrothermally altered illites (Eberl and Środon 1988), and on regionally metamorphosed pelitic schists (Cashman and Ferry 1988), show that Ostwald ripening is characterized by bell-shaped frequency histograms, positively skewed to larger crystal sizes. With advancing grade the location of the maximum sizefrequency moves to larger crystal sizes, as smaller crystals are reduced in size and eventually disappear. This is clearly the pattern of changing grain-size distribution with advancing grade, shown in Figs. 6 and 7.

In terms of effective crystallite size $N_{(001)}$, the point at which neomorphic white mica becomes sufficiently abundant and well oriented to constitute a pervasive fabric will depend partly on initial lithology. Pelitic rocks 
in the Welsh Basin show pervasive cleavage development at Kubler indices less than $0.37-0.35 \Delta^{\circ} 2 \theta\left(N_{(001)}=26-\right.$ 28). In a study of slaty cleavage development in Permian-Cretaceous pelites in Japan, Ishii (1988) concluded that a Kubler index of $0.29 \Delta^{\circ} 2 \theta\left(N_{(001)}=36\right)$ is a critical one beyond which coarsening and degree of preferred orientation in both white mica and chlorite are abruptly advanced. These conclusions are consistent with the nature of the Scherrer relationship shown in Fig. 8.

The TEM size distribution and shape of the Scherrer curve in Fig. 8 has clear inplications for the choice of size fraction used to determine Kubler indices (Kisch and Frey 1987). Beyond an effective crystallite size $N_{(001)}=\sim 100$ (i.e. $0.10 \mu \mathrm{m}$ ), the Kubler index rapidly loses sensitivity. This indicates that where the dominant portion of the crystallite population lies at thicknesses $>100$ layers, it will have little influence on the $10 \AA$ peak-width, but will increase peak intensity. Effective separation of crystallite populations with $N_{(001)}=<100$ will depend on the length: thickness ratio of white-mica crystallites. Ratios tend to decline as grade increases, from >40:1 (length: thickness) in the diagenetic mudstone (BRM 202), to 20:1 (or less) in the epizonal slate (BRM 167); the ratio is $<10: 1$ in the synthetic fluorophlogopite mica used to measure machine broadening (p. 38). If a length: thickness ratio of $20: 1$ is assumed for epizonal pelites then some proportion of the crystallite population with $N_{(001)}=<100$ layers $(0.10 \mu \mathrm{m})$ will reach $3 \mu \mathrm{m}$ or more in length, and will therefore be excluded from the customary $<2 \mu \mathrm{m}$ separations used to determine Kubler indices. However if ratios are less than $20: 1$, or the separation procedure is less than rigorous (most separation techniques err on the side of shorter rather than longer settling times), then most crystallites making a significant contribution to the peak profile should be contained in the $<2 \mu \mathrm{m}$ separations. There seems little justification, from this study, for using 2 $6 \mu \mathrm{m}$ separations (Weber 1972), and the practise of removing the $<0.1 \mu \mathrm{m}$ fraction from $<2 \mu \mathrm{m}$ separations prior to XRD, referred to in Kisch and Frey (1987, p. 302 ), should be discontinued.

\section{Conclusions}

Three pelitic rocks, representing a prograde transition from diagenetic mudstone thouch anchizonal to epizonal slate, show a prograde increase in white mica crystallite size, coupled with a decrease in the width of the $10 \AA$ peak-profile, the Kubler index. The TEM lattice-fringe measurements of the thickness of white mica crystallites show that the mode of the size populations of the diagenetic and anchizonal rocks can be correlated with the effective crystallite size $N_{(001)}$ as determined by XRD measurements. The mode of the TEM-measured size population of the epizonal slate does not correspond with XRD-measured $N_{(001)}$ because the greater proportion of crystallites have thicknesses in excess of $1000 \AA$ $(0.1 \mu \mathrm{m})$ and these have little influence on XRD peak broadening. These results indicate that the Kubler index measures changes in the white mica size population which result from a prograde increase in the size of defect-free X-ray scattering domains. The prograde changes measured by the Kubler index conform to the Scherrer relationship between small crystallite size and peak broadening. Lattice 'strain', in the form of smectite interlayers in white mica, appears to be confined to noncleaved diagenetic grade mudstones. Once anchizonal conditions of metamorphism are attained, lattice 'strain', either in the form of smectite interlayers or crystal defects, is relatively unimportant. A rapid increase in white mica crystallite size occurs within the anchizone and is accelerated by cleavage development. Cleavage appears to develop by the simultaneous dissolution and growth of larger phengite crystals at the expense of smaller crystallites, a grain-growth process that is characteristic of Ostwald ripening. Once epizonal conditions of metamorphism are attained white mica crystallisation has advanced close to the point where the Kubler index is no longer a sensitive indicator of grade.

This study firmly establishes that the Kubler index measures crystallographic changes in white mica that result from low grade metamorphism. The Kubler index should therefore be adopted as the preferred crystallinity technique for metapelites, as recommended by Blenkinsop (1988).

Acknowledgements. This work forms part of the BGS Wales Regional Surveys research programme and is published by permission of the Director, British Geological Survey, Natural Environment Research Council. One of us (BR) gratefully acknowledges research funding from The Royal Society. The work was made possible and was supported by NSF grants EAR-860 4170 and EAR8817080 to Donald R. Peacor. Contribution No. 464 from the Mineralogical Laboratory, Department of Geological Sciences, University of Michigan.

\section{References}

Ahn JH, Peacor DR (1986) Transmission and analytical electron microscopy of the smectite-to-illite transition. Clays Clay Miner 34:165-186

Ahn JH, Peacor DR, Essene EJ (1986) Cation-diffusion-induced characteristic beam damage in transmission electron microscope images of micas. Ultramicroscopy 19:375-382

Árkai P (1977) Low-grade metamorphism of Palaeozoic sedimentary formations of the Szendrö Mountains (NE-Hungary). Acta Geol Acad Sci Hung 21:53-80

Árkai P, Tóth MN (1983) Illite crystallinity: combined effects of domain size and lattice distortion. Acta Geol Hung 26:341-358

Árkai P, Horváth ZA, Tóth M (1981) Transitional very low- and low-grade regional metamorphism of the Palaeozoic formations, Uppony Mountains NE-Hungary: mineral assemblages, illite-crystallinity, $b_{0}$ and vitrinite reflectance data. Acta Geol Acad Sci Hung 24:265-294

Austin GS, Glass HD, Hughes RE (1989) Resolution of the polytype structure of some illitic clay minerals that appear to be 1 Md. Clays Clay Miner 37:128-134

Bevins RE, Merriman RJ (1988) Compositional controls on coexisting prehnite-actinolite and prehnite-pumpellyite facies assemblages in the Tal y Fan metabasite intrusion, North Wales: implications for Caledonian metamorphic field gradients. J Metamorphic Geol 6:17-39

Blenkinsop TG (1988) Definition of low-grade metamorphic zones using illite crystallinity. J Metamorphic Geol 6:623-636 
Cashman KV, Ferry JM (1988) Crystal size distribution (CSD) in rocks and the kinetics and dynamics of crystallization III. Metamorphic crystallization. Contrib Mineral Petrol 99:401415

Eberl DD, Środoń J (1988) Ostwald ripening and interparticlediffraction effects from illite crystals. Am Mineral 73:13351345

Eberl DD, Velde B (1989) Beyond the Kubler index. Clay Miner 24:571-577

Eberl DD, Środoń J, Lee M, Nadeau P, Northrop HR (1987) Sericite from the Silverton caldera, Colorado: correlation among structure, composition, origin, and particle thickness. Am Mineral 72:914-934

Fortey NJ (1989) Low grade metamorphism in the Lower Ordovician Skiddaw Group of the Lake District, England. Proc Yorks Geol Soc 47:325-337

Frey M (1969) A mixed-layer paragonite/phengite of low-grade metamorphic origin. Contrib Mineral Petrol 24:63-65

Frey M (ed) (1987) Low Temperature Metamorphism. Blackie and Son Ltd., Glasgow

Howells MF, Reedman AJ, Campbell SDG (1990) Ordovician (Caradoc) marginal basin volcanism in Snowdonia (NW Wales). Mem Geol Surv GB (in press)

Ishii K (1988) Grain growth and re-orientation of phyllosilicate minerals during the development of slaty cleavage in the South Kitakami Mountains, northeast Japan. J Struct Geol 10:145154

Jiang WT, Peacor DR, Merriman RJ, Roberts B (1990) Transmission and analytical electron microscopic study of mixed-layer illite/smectite formed as a apparent replacement product of diagenetic illite. Clays Clay Miner (in press)

Kisch HJ (1980) Incipient metamorphism of Cambro-Silurian clastic rocks from the Jämtland Supergroup, central Scandinavian Caledonides, western Sweden: illite crystallinity and 'vitrinite' reflectance. J Geol Soc London 137:271-288

Kisch HJ (1983) Mineralogy and petrology of burial diagenesis (burial metamorphism) and incipient metamorphism in clastic rocks. In: Larsen G, Chilinger GV (eds) Diagenesis in sediments and sedimentary rocks 2, Elsevier, Amsterdam, 289-493

Kisch HJ (1989a) Discordant relationship between degree of very low-grade metamorphism and the development of slaty cleavage. In: Cliff RA, Yardley BWD (eds) Evolution of Metamorphic Belts. Geol Soc Spec Publ 43:173-185

Kisch HJ (1989 b) Calibration of the anchizone: a critical comparison of illite 'crystallinity' scales used for definition. J Metamorphic Geol 8:31-46

Kisch HJ, Frey M (1987) Effect of sample preparation on the measured $10 \AA$ peak width of illite (illite 'crystallinity'). In: Frey M (ed) Low temperature metamorphism. Blackie and Son Ltd., Glasgow, 301-304

Klug HP, Alexander LE (1974) X-ray Diffraction Procedures, 2nd edn. Wiley, New York

Knipe RJ (1981) The interaction of deformation and metamorphism in slates. Tectonophysics $78: 249-272$

Kreutzberger ME, Peacor DR (1988) Behaviour of illite and chlorite during pressure solution of shaly limestone of the Kalkberg Formation, Catskill, New York. J Struct Geol 10:803-811

Kubler B (1964) Le argiles, indicateurs de métamorphisme. Rev Inst Fr Pet 19:1093-1112

Kubler B (1967) Le cristallinité de l'illite et les zones tout à fait superieures du métamorphisme. In: Étages tectoniques. Colloque de Neuchâtel, pp 105-121

Kubler B (1968) Evaluation quantitative du métamorphisme par la cristallinité de l'illite. Bull Cent Rech Pau SNPA 2:385-397

Kubler B (1984) Les indicateurs des transformations physiques et chimiques dans la diagenèse, températeure et calorimétrie. In: Lagache M (ed) Thermométrie et barometrie géologiques. Soc Fr Minéral Cristallogr Paris:489-596

Lee JH, Peacor DR, Lewis DD, Wintsch RP (1984) Chlorite-illite/ muscovite interlayered and interstratified crystals: a TEM/ STEM study. Contrib Mineral Petrol 88:372-385

Lee JH, Ahn JH, Peacor DR (1985) Textures in layered silicates: Progressive changes through diagenesis and low-temperature metamorphism. J Sediment Petrol 55:532-540

Lee JH, Peacor DR, Lewis DD, Wintsch RP (1986) Evidence for syntectonic crystallisation for the mudstone to slate transition at Lehigh Gap, Pennsylvania, U.S.A. J Struct Geol 8:767-780

Livi KJT, Veblen DR, Ferry JM (1988) Electron microscope study of anchizone and epizone metamophosed shales from the Central Swiss Alps (abstract). Geol Soc Am Abstracts Program $20: 244$

Merriman RJ, Roberts B (1985) A survey of white mica crystallinity and polytypes in pelitic rocks of Snowdonia and Llyn, North Wales. Mineral Mag 49:305-319

Milodowski AE, Zalasiewicz JA (1990) The origin, deposition and prograde evolution of chlorite-mica stacks in Llandovery sediments of the central Wales Basin. Geol Mag (in press)

Ostwald W (1900) Über die vermeintliche Isomeric des roten und gelben Quecksilberoxyds und die Oberflächenspannung fester Körper. Z Phys Chem Stoechiom Verwandtschaftsl 34:495-503

Pesquera A, Velasco F (1988) Metamorphism of the Palacozoic Cinco Villas massif (Basque Pyrenees): illite crystallinity and graphitization degree. Mineral Mag 52:615-625

Roberts B (1979) The Geology of Snowdonia and Llyn. Adam Hilger Ltd., Bristol

Roberts B (1981) Low grade and very low grade regional metabasic Ordovician rocks of Llyn and Snowdonia, Gwynedd, North Wales. Geol Mag 118:189-200

Roberts B, Merriman RJ (1985) The distinction between Caledonian burial and regional metamorphism in metapelites from North Wales: an analysis of isocryst patterns. J Geol Soc London 142:615-624

Roberts B, Merriman RJ (1990) Cambrian and Ordovician metabentonites and their relevance to the origins of associated mudrocks in the northern sector of the Lower Palaeozoic Welsh marginal basin. Geol Mag 127:31-43

Roberts B, Evans JA, Merriman RJ, Smith M (1989) Discussion on low grade metamorphism of the Welsh Lower Palaeozoic succession: an example of diastathermal metamorphism? J Geol Soc London 146:885-890

Roberts B, Morrison C, Hirons S (1990) Low grade metamorphism of the Manx Group, Isle of Man: a comparative study of white mica 'crystallinity' techniques. J Geol Soc London 147:271277

Robinson D, Bevins RE (1986) Incipient metamorphism in the Lower Palaeozoic marginal basin of Wales. J Metamorphic Geol 4:101-113

Shau Y-H, Feather ME, Essene EJ, Peacor DR (1990) Genesis and solvus relations of submicroscopically intergrown paragonite and phengite in a blueschist from Northern California. Contrib Mineral Petrol (in press)

Środoń J (1984) X-ray diffraction of illitic materials. Clays Clay Miner 32:337-349

Środon J, Andreoli C, Elass F, Robert M (1990) Direct HRTEM measurement of expandability of mixed-layer illite/smectite in bentonite rock. Clays Clay Miner (in press)

Veblen DR (1985) Direct TEM imaging of complex structures and defects in silicates. Annu Rev Earth Planet Sci 13:119-146

Weber F, Dunoyer de Segonzac G, Economou C (1976) Une nouvelle expression de la 'cristallinité' de l'illite et des micas. Notion d"épaisseur apparente' des cristallites. CR Somm Soc Geol Fr 5:225-227

Weber K (1972) Notes on the determination of illite crystallinity. Neues Jahrb Mineral Monatsh 1972:267-276

Editorial responsibility: I. Parsons 